\title{
scripted
}

Volume 15, Issue 1, August 2018

\section{Book review: Digital Democracy in a Globalized World}

Corien Prins, Colette Cuijpers, Peter L. Lindseth, Monica Rosina (eds.) Cheltenham, Glos UK: Edward Elgar Publishing Ltd, 2017. 375 pages. ISBN $9781785363955 . £ 110$.

Reviewed by Joseph Savirimuthu*

(ㄷ) (ㄱ) $\odot$

(C) 2018 Joseph Savirimuthu

Licensed under a Creative Commons Attribution-NonCommercial-No

Derivatives 4.0 International (CC BY-NC-ND 4.0) license

DOI: $10.2966 /$ scrip.150118.149

* Senior Lecturer in Law, Liverpool Law School, University of Liverpool, Liverpool, UK, javiri@liverpool.ac.uk 
The democratic project is to globalize democracy as we have globalized the economy; to democratize the globalism that has been so efficiently marketized. ${ }^{1}$

Digital Democracy in a Globalized World (Digital Democracy) is an edited collection of essays which is the product of the efforts of the Law Schools Global League working group on "Digital Democracy" (p. xii). Readers should banish any thoughts about this book containing a manifesto for a gilded age for democracy. And rightly so. ${ }^{2}$ Democracy is a word that is not new and the impact of globalisation in promoting its values continues to be hotly debated. Digitalisation is unlikely to relieve us from the challenges facing democracy in a global economy. The open and decentralised nature of the Internet is also likely to exacerbate the blindspots in cultural and political conceptions of democracy. ${ }^{3}$ Additionally, the persistence of disagreements over the connection between democracy and globalisation is symptomatic of the longstanding arguments about the relationship between markets, civil society and democracy. Those who control access to resources and platforms for communication in the digital economy possess considerable power and technological capabilities to structure and reconfigure discourses by controlling access to resources and spaces for flows of information. Castell may have been alluding to the problematic nature of blindspots inherent in the economic imperatives and questionable mainstreaming of the Schumpeterian logic of the double helix of democracy and

1 Benjamin Barber, Jihad vs. McWorld: How Globalism and Tribalism Are Reshaping the World (New York: Ballantine Books, 1996), p. xxiii.

2 Sascha Dickel and Jan-Felix Schrape, "The Logic of Digital Utopianism” (2017) 11(1) NanoEthics 47-58; Cristina Groeger, "Learning Democracy in a New Gilded Age" (2017) 16(4) The Journal of the Gilded Age and Progressive Era 385-387.

3 Richard Sennett, "The Spaces of Democracy" in Robert Beauregard and Sophie BodyGendrot (eds.), The Urban Moment: Cosmopolitan Essays on the late Twentieth Century City (Thousand Oaks, CA: Sage, 1999), pp. 273-286. 
globalisation since "the expression of the network of flows whose architecture and content is determined by the powers that be in our world." 4

Even though it is too early to make judgments about the future of democracy (in both its analogue and digital variants), the collection of essays in Digital Democracy aims to provide readers with concrete manifestations of the practice and experience of democracy in spaces mediated by technologies and platform infrastructures. As the title to the book implies, information and communication technologies are creating a truly global society. Contemporary illustrations of the exercise of democratic power or the worrying consequences resulting from the commodification of public and private spaces for democracy and what this implies for the normative conditions critical to the democratic project are not difficult to find. The foregoing observations should by now remind us that the democracy project is vast and attending to the spectrum of decision-making, participation and governance cannot be meaningfully undertaken in one book. The editors of Digital Democracy make it clear at the outset that the aim of the book is not to resolve "the question of democracy" in the age of information flows and global technology corporations, but to explore its meanings and its visible indicators in mediated spaces for civic engagement, political interaction and discourse (pp. 4-8).

Digital Democracy has 16 chapters, divided into two main parts lending theoretical and comparative analysis with case studies focussing on a number of countries. There are 27 contributors and each chapter is the product of careful research and supported by extensive footnotes and references. It would have been helpful if a full bibliography was provided at the end of each chapter. The

4 Manuel Castells, The Rise of the Network Society (Chichester: Wiley-Blackwell, 2010), p. 443. See also Mahzarin Banaji and Anthony Greenwald, Blindspot: Hidden Biases of Good People (New York: Delacorte Press, 2013). 
six chapters in Part One examine topics such as citizenship, multi-stakeholder governance, and the problems globalisation pose to the integrity of the democratic process. These chapters provide three frames for thinking about the relationship between technology, power and the conditions for democratic discourse and engagement. It is important to recognise the contingency of these techniques when reflecting on the symbiotic character of the interactions that take place within democratised spaces when addressing the difficult policy and regulatory challenges faced when designing technology to serve democratic goals or formulating appropriate responses to prevailing cultural and social conditions (pp. 40-46, 74-76, 84-91, 108-111, 125-132, 154-158). The premise for the discussion in this Part should not go unobserved - technology is now regarded as integral to formulating a vision of a truly democratic global society (pp.43-52, 67-76). The "technological lens" and data-driven processes assume a pivotal role in managing cultural, educational and technological challenges while at the same time ensuring that implementation issues are resolved and the spaces for democratisation are not hindered by outdated policies or conflicts of interests (pp. 81-84, 111-119, 128-140).

Issues relating to the socialisation of power and the policy challenges confronting jurisdictions are expertly addressed in Part Two. The eight chapters in this Part reinforce the received wisdom that democracies are by nature and definition pluralist (p. 5). Is democracy now dependent on technology (pp. 214247, 259-269)? If so, what type of utopias are being elevated, and in whose interests (pp. 278-282)? These are some of the questions that may help better problematise the case studies provided in Part Two. The questions may sound academic or esoteric but it is important to be aware that ignoring them can have adverse consequences for individuals and goes to the core of the ambitions of any project that aims to harness the opportunities globalisation provides for democracy (pp. 183-185, 272-273, 315-325, 332-341). The legitimacy of decision- 
making, rule-making and control of power which impacts the daily lives of citizens makes it imperative that any version of democracy being promoted must adhere at the very least to establishing the necessary normative and cultural conditions for meaningful participation (pp. 169-179), identifying and engineering deliberative democracy values (pp. 186-198, 207-209), developing strategies to grapple with information asymmetries and power imbalance (pp. 189-191, 210-218), managing cultural expectations and monitoring the quality of democratic engagement (pp. 218-226) and at all times retaining a healthy scepticism to those who regard technology as the modern Prometheus (pp. 230231, 253-259, 282-298). These chapters provide some granular insights into "ground zero": reflections on the contributions of governments and the private sector to promoting democracy and highlighting some of their limitations. Can we regard these case studies as examples of the democratisation of society and by extension the legitimation of the strategies which invariably involve some element of "trade-off" (pp. 35-37, 49-50, 56-57, 94-95, 118-119, 138-139, 178, 302307)? Does digital democracy require smart or at least digitally literate citizens?

Answers to both questions cannot be found in Digital Democracy owing to a lack of clarity regarding the methodology or conceptions of democracy to be brought into play. Notwithstanding this challenge, Peter Lindseth rightly emphasises the cautious, if not cautionary tone of Digital Democracy. While the practical manifestations of technology on spaces for the practice of democracy will be both disruptive and revolutionary, a critique that embraces the "ontological turn" would have been equally insightful (p. 345). ${ }^{5}$ Peter Lindseth concludes with the observation in respect of the instrumental value of technology for democracy but recognises the challenge it also poses to societies and

5 Mihaela Mihai et al., “Democracy, Critique and the Ontological Turn" (2017) 16(4) Contemporary Political Theory 501-531. 
policymakers (p. 364). The contingency of the instrumental value of technology for democratisation is a theme that runs through throughout the book. If technology is indeed a game-changer, how do we frame the cultural shift that is required and the safeguards implemented when platforms for decision-making and governance are marketised or controlled by those in power? The value of these questions to Digital Democracy may not seem readily apparent until one probes closely into the Faustian nature of the space of flows for democracy. Flows of information orchestrated by algorithmic processes leveraging multiple data sets controlled by the State and global elites, may help democratise some aspects of decision-making and participation. Equally, the invisible nature of data driven processes, the logic of commodifying public and private spaces and the design choices of affordances and interfaces can also undermine the very foundations of democracy - the public space for digital democracy requires at a minimum equality of access not only to resources but to participation and decisionmaking. ${ }^{6}$

We are given a glimpse of the consequences for democracy when spaces for discourse are reconfigured in a way that embeds imbalances in power and information asymmetries - the vote to leave the European Union, the election of President Trump, and the allegedly undue influence by those campaigns. Should we have less digital democracy and more meaningful politics in public spaces for democracy? ${ }^{7}$ Is democracy being reconfigured by technologies of power in an environment where the boundaries between politics, economy and markets have become self-referential? ${ }^{8}$ Digital Democracy is an invaluable

6 Jürgen Habermas, "Three Normative Models of Democracy" in Steven Cahn (ed.), Political Philosophy: The Essential Texts (Oxford: Oxford University Press, 2005), p. 527.

7 David Runciman, Political Hypocrisy: The Mask of Power, from Hobbes to Orwell and Beyond (Princeton, NJ: Princeton University Press, 2010).

8 Michael Walzer, “Philosophy and Democracy” (1981) 9(3) Political Theory 379-399. 
resource and should be read by everyone with an interest in regulation, governance and politics. It is not a book that will help us answer two important questions raised by the spaces for democracy that are being digitalised and situated in the global marketplace: is democracy possible here and how will the democratic project towards globalised democracy end? ${ }^{9}$ That said, Digital Democracy will provide the tools and inspiration to help demonstrate our commitment to democracy.

9 Ronald Dworkin, Is Democracy Possible Here? Principles for a New Political Debate (Princeton, NJ: Princeton University Press, 2006). 